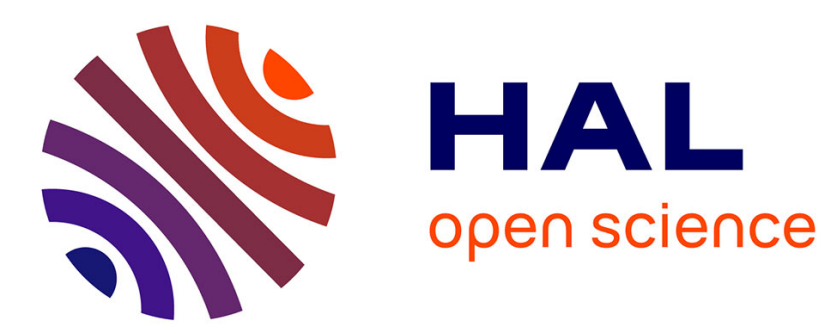

\title{
Fatty Acid Compositions of Olive Oils from Six Cultivars from East and South-Western Algeria
}

Nora Boudour-Benrachou, Jérôme Plard, Christian Pinatel, Jacques Artaud, Nathalie Dupuy

\section{- To cite this version:}

Nora Boudour-Benrachou, Jérôme Plard, Christian Pinatel, Jacques Artaud, Nathalie Dupuy. Fatty Acid Compositions of Olive Oils from Six Cultivars from East and South-Western Algeria . Adv Food Technol Nutr Sci Open J, 2017, 3 (1), pp.1 - 5. 10.17140/AFTNSOJ-3-138 . hal-01666628

\section{HAL Id: hal-01666628 https://hal.science/hal-01666628}

Submitted on 13 Apr 2018

HAL is a multi-disciplinary open access archive for the deposit and dissemination of scientific research documents, whether they are published or not. The documents may come from teaching and research institutions in France or abroad, or from public or private research centers.
L'archive ouverte pluridisciplinaire HAL, est destinée au dépôt et à la diffusion de documents scientifiques de niveau recherche, publiés ou non, émanant des établissements d'enseignement et de recherche français ou étrangers, des laboratoires publics ou privés. 


\section{ADVANCES IN FOOD TECHNOLOGY AND NUTRITIONAL SCIENCES}

\section{Research}

\section{*Corresponding author}

Nora Boudour-Benrachou, PhD

Institut des Sciences Agronomique

Université Chadli Bendjedid/El Tärf

Algeria

E-mail: nora.benrachou@gmail.com

Volume 3 : Issue 1

Article Ref. \#: 1000AFTNSOJ3138

\section{Article History}

Received: November $19^{\text {th }}, 2016$

Accepted: March $3^{\text {rd }}, 2017$

Published: March 3rd, 2017

\section{Citation}

Boudour-Benrachou N, Plard J, Pinatel C, Artaud J, Dupuy N. Fatty acid compositions of olive oils from six cultivars from East and SouthWestern Algeria. Adv Food Technol Nutr Sci Open J. 2017; 3(1): 1-5. doi: 10.17140/AFTNSOJ-3-138

\section{Copyright}

(C2017 Boudour-Benrachou N. This is an open access article distributed under the Creative Commons Attribution 4.0 International License (CC BY 4.0), which permits unrestricted use, distribution, and reproduction in any medium, provided the original work is properly cited.

\section{Fatty Acid Compositions of Olive Oils from Six Cultivars from East and South-Western Algeria}

\author{
Nora Boudour-Benrachou, $\mathrm{PhD}^{1 *}$; Jérôme Plard, $\mathrm{PhD}^{2}$; Christian Pinatel, $\mathrm{PhD}^{3}$; Jacques \\ Artaud, $\mathrm{PhD}^{2}$; Nathalie Dupuy, $\mathrm{PhD}^{2}$
}

${ }^{1}$ L'Institut des Sciences Agronomique, Université Chadli Bendjedid/El Tärf, Algeria ${ }^{2}{ }^{2} S M^{2}$, UMR 6263, Equipe AD²EM, Université Paul Cézanne, Case 451, 13397 Marseille Cedex 20, France

${ }^{3}$ Centre Technique de l'olivier (CTO), Maison des Agriculteurs, 22 Avenue Henri Pontier, 13626 Aix-en-Provence Cedex, France

\section{ABSTRACT}

The aim of this work is to characterize olive oils from six algerian cultivars (Azeradj, $\mathrm{n}=4$ ); Blanquette, $\mathrm{n}=7$; Bouricha, $\mathrm{n}=2$; Chemlal, $\mathrm{n}=5$; Limli, $\mathrm{n}=3$; Sigoise, $\mathrm{n}=1$ ) by determining their fatty acid compositions. The fatty acid composition of oils is determined using gas chromatography of methyl esters obtained by transesterification of triacylglycerols with $2 \mathrm{M} \mathrm{KOH} / \mathrm{MeOH}$. Fourteen fatty acids and squalene are identified in all the samples. Oleic acid (18:1 09$)$, palmitic

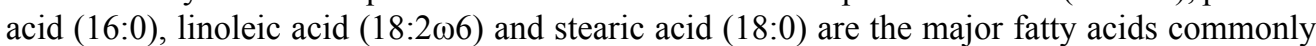

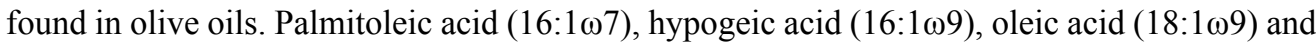
cis-vaccenic acid $(18: 1 \omega 7)$ are considered as separate entities by the European regulation, unlike the Codex Alimentarius which identifies them as a single component. Six minor fatty acids

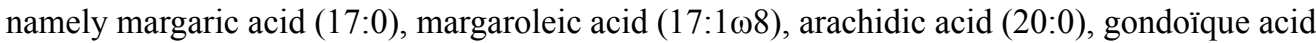
$(20: 1 \omega 9)$, behenic acid (22:0) and lignoceric acid (24:0) are identified. These acids, although minor, are important for the characterization of cultivars. Oils of different cultivars are characterized by different fatty acid compositions. All the values of fatty acid compositions are in compliance with the regulations of the International Olive Oil Council and Codex Alimentarius. A radial plot enables the analysis and characterization of each variety as a "morphotype" by creating a "morphogramme". The "morphogramme" is designed as a radial representation of each fatty acid $(n=14)$ using an Excel $^{\circledR}$ spreadsheet, and each axis represents the change in the variable with respect to the mean. The "morphotypes" are real fingerprints of different oil cultivars. Thus, the oils of Azeradj, Blanquette, Chemlal, Limli and Sigoise cultivars have specific "morphotype". The "morphotype" of the Bourricha cultivar is very similar to the Chemlal cultivar. In addition, the Blanquette "morphotype" is identical to that of the tunisian cultivar Chetoui. This mode of representation is particularly effective for the rapid visual identification of characteristics of olive oils.

KEY WORDS: Algerian cultivar; Fatty acids; Olive oil; "Morphotype".

ABBREVIATIONS: PDO: Protected Designation of Origin; NADP: National Plan for Agricultural Development; FAME: Fatty Acid Methyl Esters; FID: Flame Ionization Detector; VOOs: Virgin Olive Oils.

\section{INTRODUCTION}

The characterization of olive oils in terms of cultivars and geographical origin is a matter of current debate. The quality and the peculiarity of olive oil is, in fact, influenced by several factors one of them being the associated cultivar. ${ }^{1}$ 
Open Journal

Algeria currently has almost $32 \times 10^{6}$ olive trees covering an area of 310,000 ha. Reports of NADP (National Plan for Agricultural Development) indicate that Algeria will achieve an overall coverage area of 420,000 ha in some years. ${ }^{2}$ The Algerian olive grove is rich in varieties, despite which only a few systematic studies have been conducted on the local cultivars to evaluate the quality of oil which is a priority relative to the requirements of the international market and international olivegrowing council (COI). The authentication of virgin olive oils (VOOs) has always been a problem of topical interest. The determination of the varietal origin of oils is important for quality control in the food industry and to assure fair trading. We have shown that the fatty acid composition of monovarietal olive oils or French protected designation of origin (PDO) oils were distinct characteristics of the cultivar or the geographical origin of olive oils. ${ }^{3,4}$

So, the aim of the present study is to investigate the varietal characterization of olive oils from six Algerian cultivars (Azeradj, Blanquette, Bouricha, Chemlal, Limli, Sigoise) by determining their fatty acid compositions and to create a "morphotype" for each cultivar. This data will be particularly effective in ensuring a possible protected designation of origin, their protection from related fraudulence activities, ${ }^{5}$ and in improving the quality of our oils by utilizing potential varieties taking the chemical composition of oil into account, to fulfill the requirements of the international market with respect to the commercial standards.

\section{MATERIALS AND METHODS}

\section{Oil Samples}

The samples came from the east and north-east of Algeria. Figure 1 represents the Algerian olive growing areas. Industrial virgin olive oil samples $(n=22)$ were collected during two crop harvesting seasons (2009 and 2010). Oils came from six Algerian cultivars: Azeradj ( $\mathrm{n}=4$; Bejaia, Skikda), Blanquette $(\mathrm{n}=7$; Guelma, Soouk-Ahras), Bourricha ( $\mathrm{n}=2$; Skikda), Chemlal $(\mathrm{n}=5$; Bourmerdes, Setif, Tarf, Tebessa, Tizi-ouzou), Limli $(\mathrm{n}=3$; Jijel) and Sigoise (n=1; El-Oued).

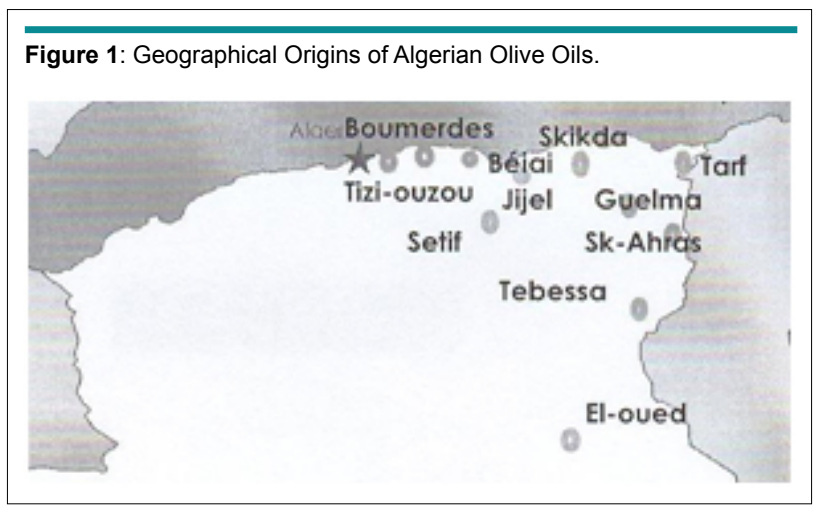

\section{Fatty Acid Determination}

Olive oil in $n$-heptane $(0.12 \mathrm{~g} / 2 \mathrm{~mL})$ were transmethylated with a cold solution of $\mathrm{KOH}(2 \mathrm{M})(200 \mu \mathrm{l})$ according to the norms of the European Standard NF EN ISO 5509 (2000). ${ }^{6}$ Fatty acid methyl esters (FAME) were analyzed in compliance with the European Standard NF EN ISO 5508 Norms (1995). The experimental analysis were performed using an Agilent Technology gas chromatograph 7890 A (GC) equipped with a split/split-less injector $\left(t=250^{\circ} \mathrm{C}\right)$ and a flame ionization detector (FID) $(t=250$ $\left.{ }^{\circ} \mathrm{C}\right)$. A silica capillary column $(60 \mathrm{~m} \times 0.25 \mathrm{~mm}$ i.d., $0.25 \mu \mathrm{m}$ film thickness) coated with Sulpelcowax (Supelco) were used. The operating conditions of separation were such that the gas carriers (hydrogen) were used as the output. The inlet pressure of the hydrogen as carrier gases were $178 \mathrm{\kappa Pa}$ with the ratio $1: 70$. The oven temperature conditions were as follows: $20 \mathrm{~min}$ at $210^{\circ} \mathrm{C}$, from $210{ }^{\circ} \mathrm{C}$ to $245{ }^{\circ} \mathrm{C}$ at $6{ }^{\circ} \mathrm{C} / \mathrm{min}, 20 \mathrm{~min}$ at $245{ }^{\circ} \mathrm{C}$ and the flow rate were $13 \mathrm{ml} / \mathrm{mn}$. The peaks were identified on the basis of the retention of known methyl esters.

\section{Morphogramme}

A radial plot helps create a "morphogramme" which is used in the characterization of each variety as per a "morphotype". The "morphogramme" is designed as a radial representation using an Excel ${ }^{\circledR}$ spreadsheet, and on each axis the change in the variable with respect to the mean is represented. For each variable, centered mean gives the origin of the graphics $(0 \%)$ that comes from a data base built from more than 2000 samples from various sources, grouped on the basis of variety and origin. The limits of variation $(-100 \%$ to $+100 \%)$ is equal to twice the standard deviation of the variable for fatty acids. The solid lines are the median values of individual fatty acids with respect to the dotted lines of first and second quartiles. Thus, on each axis, the value represented gives the percentage change compared to two times the standard deviation.

\section{Nomenclature}

The nomenclature of the fatty acids that were found in our study has been given as follows: Fatty acids 14:0, myristic acid (tetradecanoic acid); 16:0, palmitic acid (hexadecanoic acid); hypogeic acid (7-hexadecenoic acid); palmitoleic acid (9-hexadecenoic acid); 17:0, margaric acid (heptadecanoic acid); margaroleic acid (9-heptadecenoic acid); oleic acid (9-octadecenoic acid); cis vaccenic acid (11-octadecenoic acid); linoleic acid (9,12-octadecadienoic acid); linolenic acid (9,12,15-octadecatrienoic acid); 20:0, arachidic acid (eicosanoic acid); gondoic acid (11-eicosenoic acid) ${ }^{2} ; 22: 0$, behenic acid (docosanoic acid); 24:0, lignoceric acid (tetracosanoic acid).

\section{RESULTS AND DISCUSSION}

The fatty acid composition of oils were determined by gas chromatography of methyl esters. Fourteen fatty acids and squalene were identified in all samples. Oleic acid (18:1 $\omega 9)$, palmitic acid 
Open Journal $\odot$

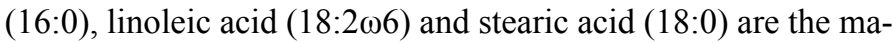
jor fatty acids commonly found in olive oils. Palmitoleic acid

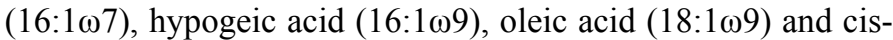

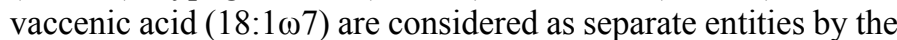
European regulation, unlike the Codex Alimentarius which identifies them as a single component. Six minor fatty acids including margaric acid (17:0), margaroleic acid (17:1 $\omega 8)$, arachidic acid (20:0), gondoïque acid (20:1 $\omega 9),{ }^{2}$ behenic acid (22:0) and lignoceric acid (24:0) were also determined. The fatty acids which leave slight traces $(<0.01 \%)$ are not taken into account. Table 1 gives the results of the qualitative analysis of fatty acids of olive oils extracted from six cultivars. The "morphogrammes" are built from average values of fatty acids (Figure 2).

The profile of the fatty acids of the studied oils were in accordance with that of the International Olive Oil Council's regulation, ${ }^{7}$ Codex Alimentarius ${ }^{8}$ and European Regulations ${ }^{9}$ ex-

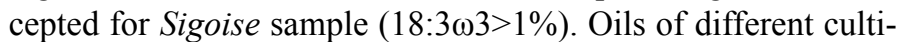
vars are characterized by different fatty acid compositions.

Our observations indicate that indeed, all the six varieties are very rich in oleic acid (C18: 1 19$)$. The flow rate of oleic acid in each studied variety for Azeradj is (72.70\%) on average, followed by the Blanquette (67.18\%), Bouricha (64.29\%),

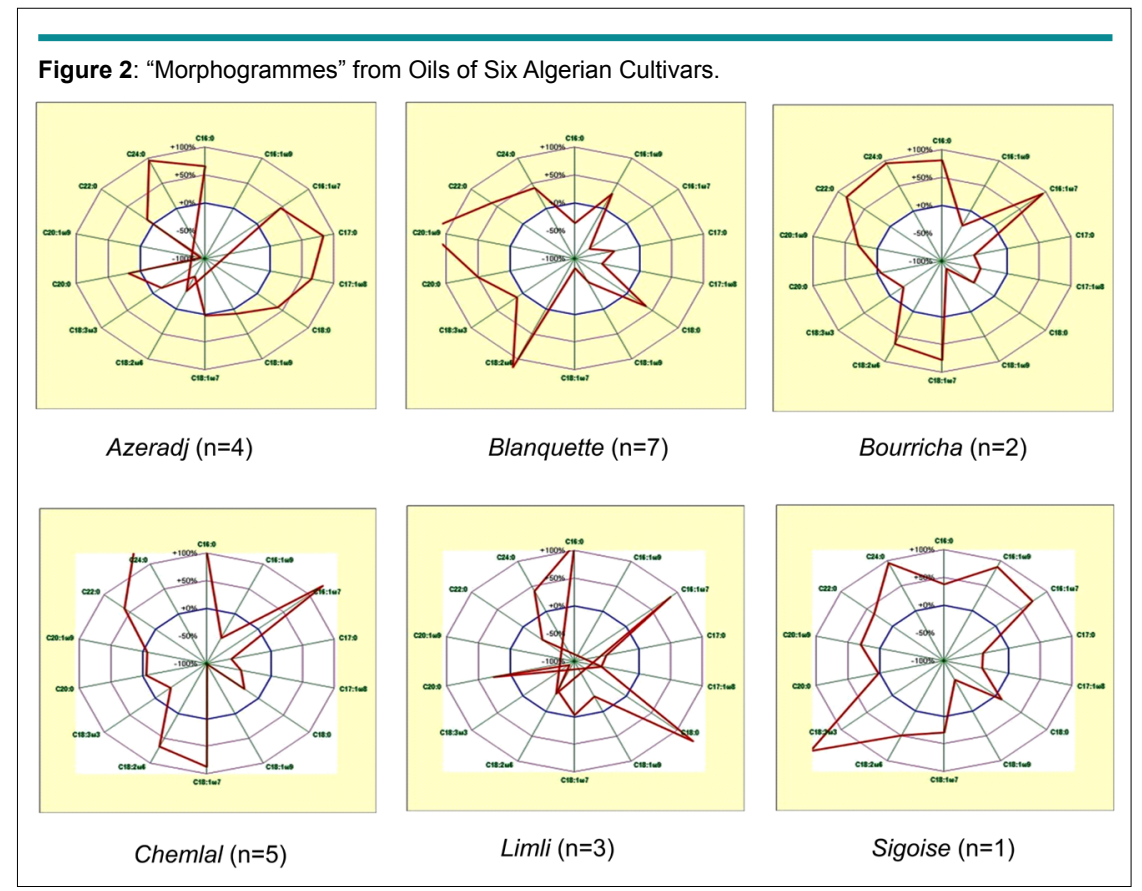

\begin{tabular}{|c|c|c|c|c|c|c|c|c|c|c|c|c|c|c|c|c|}
\hline \multirow[t]{3}{*}{ Fattyacids } & \multicolumn{3}{|c|}{ Azeradj } & \multicolumn{3}{|c|}{ Blanquette } & \multicolumn{3}{|c|}{ Bouricha } & \multicolumn{3}{|c|}{ Chemlal } & \multicolumn{3}{|c|}{ Limli } & \multirow{3}{*}{$\begin{array}{c}\text { Sigoise } \\
\mathrm{n}=1\end{array}$} \\
\hline & & $n=4$ & & & $n=7$ & & & $n=2$ & & & $n=5$ & & & $n=3$ & & \\
\hline & Min & Max & Moy & Min & $\operatorname{Max}$ & Moy & Min & Max & Moy & Min & Max & Moy & Min & Max & Moy & \\
\hline $16: 0$ & 13.12 & 14.54 & 14.01 & 9.54 & 11.66 & 10.77 & 14.31 & 14.72 & 14.51 & 14.12 & 16.29 & 15.18 & 15.17 & 15.84 & 15.47 & 13.12 \\
\hline $16: 1 \omega 9$ & 0.02 & 0.08 & 0.04 & 0.13 & 0.14 & 0.14 & 0.10 & 0.12 & 0.11 & 0.08 & 0.12 & 0.10 & 0.04 & 0.05 & 0.04 & 0.17 \\
\hline $16: 1 \omega 7$ & 1.10 & 1.44 & 1.26 & 0.23 & 0.36 & 0.33 & 1.63 & 1.68 & 1.65 & 1.43 & 2.18 & 1.90 & 1.40 & 1.93 & 1.59 & 1.47 \\
\hline $17: 0$ & 0.10 & 0.20 & 0.16 & 0.05 & 0.05 & 0.05 & 0.04 & 0.04 & 0.04 & 0.03 & 0.04 & 0.03 & 0.04 & 0.04 & 0.04 & 0.05 \\
\hline $17: 1 \omega 8$ & 0.17 & 0.32 & 0.27 & 0.06 & 0.06 & 0.06 & 0.08 & 0.09 & 0.09 & 0.07 & 0.09 & 0.08 & 0.06 & 0.07 & 0.06 & 0.09 \\
\hline 18:0 & 2.54 & 2.95 & 2.74 & 2.58 & 2.80 & 2.71 & 1.84 & 1.93 & 1.88 & 1.83 & 2.15 & 2.01 & 3.46 & 3.97 & 3.73 & 2.43 \\
\hline $18: 1 \omega 9$ & 71.38 & 74.52 & 72.70 & 64.86 & 68.79 & 67.18 & 64.11 & 64.47 & 64.29 & 60.83 & 64.52 & 63.06 & 68.73 & 68.98 & 69.19 & 66.37 \\
\hline $18: 1 \omega 7$ & 2.28 & 2.58 & 2.42 & 1.14 & 1.48 & 1.37 & 3.27 & 3.40 & 3.34 & 3.68 & 3.20 & 3.46 & 2.14 & 2.73 & 2.35 & 2.75 \\
\hline $18: 2 \omega 6$ & 4.44 & 5.44 & 4.95 & 13.97 & 16.85 & 15.65 & 12.43 & 12.70 & 12.57 & 11.48 & 13.80 & 12.69 & 6.27 & 6.33 & 6.30 & 11.66 \\
\hline $18: 3 \omega 3$ & 0.60 & 0.67 & 0.63 & 0.61 & 0.78 & 0.69 & 0.57 & 0.65 & 0.61 & 0.51 & 0.69 & 0.60 & 0.45 & 0.55 & 0.47 & 1.01 \\
\hline 20:0 & 0.40 & 0.42 & 0.41 & 0.43 & 0.49 & 0.45 & 0.38 & 0.38 & 0.38 & 0.36 & 0.42 & 0.38 & 0.41 & 0.44 & 0.42 & 0.39 \\
\hline 20:1 w9 & 0.20 & 0.25 & 0.21 & 0.38 & 0.42 & 0.39 & 0.30 & 0.32 & 0.31 & 0.24 & 0.31 & 0.28 & 0.16 & 0.18 & 0.17 & 0.31 \\
\hline 22:0 & 0.11 & 0.13 & 0.12 & 0.13 & 0.15 & 0.14 & 0.15 & 0.15 & 0.15 & 0.12 & 0.15 & 0.14 & 0.10 & 0.10 & 0.10 & 0.13 \\
\hline 24:0 & 0.07 & 0.08 & 0.07 & 0.06 & 0.07 & 0.06 & 0.07 & 0.07 & 0.07 & 0.07 & 0.09 & 0.08 & 0.05 & 0.08 & 0.06 & 0.07 \\
\hline
\end{tabular}


Open Journal

The fatty acid composition of Bouricha and Chemlal Chemlal (63.73\%), Limli (69.19\%) and $66.37 \%$ for Sigoise (Table 1).

The recorded percentage were close to those of the Tunisian varieties Chemlal, Chetoui and Zelmati which are $60.62 \%$, $65.66 \%$ and $62.15 \%$ respectively ${ }^{10}$ like those of the French oil AOC Aix en-provence et Vallée des Baux. ${ }^{11}$

These results show that the six varieties of olive oils contain considerable quantities of essential fatty acids, in particular the Blanquette variety which contains $15.65 \%$ of linoleic acid followed by oils of the varieties Chemlal and Bouricha having $12.69 \%$ and $12.57 \%$ of $18: 2 \omega 6$ respectively.

In addition, percentage of linolenic acid 18:3 $\omega 3$ constitution varies between 0.47 to $0.69 \%$ on an average for Azeradj, Blanquette, Bouricha, Chemlal and Limli except for the Sigoise sample.

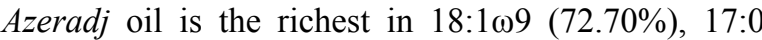
$(0.16 \%)$ and $17: 1$ and the poorest in $18: 2 \omega 6$ (4.95\%) composition. These results are in agreement with the works of Bakhouche et al, ${ }^{12}$ on the olive oils of Azeradj variety cultivated in Algeria, where the oleic acid composition ranges between 55 to $83 \%$ and low values of linoleic acid. However, to analyse the composition of an essential fatty acid, Blanquette is the most promising variety following the Chemlal and Bouricha.

It should be noted that the average percentages in linoleic and linolenic acid composition in six oils during the 2-seasons prove to be sufficient to prevent a state of deficiency of fatty acids for the people using this as principal source of fat in their food. ${ }^{13}$ oils are similar. The "morphogrammes" allow the identification of "morphotypes" for each variety of oil. The Bouricha and Chemlal "morphogrammes" (Figure 2) confirm the resemblance between them. Moreover, the Blanquette "morphotype" is identical to that of the Tunisian cultivar Chetoui (Figure 3). This confirms the hypothesis of Loussert and Brousse ${ }^{14}$ on the identity and resemblance between these two cultivars.

This mode of representation is particularly effective to allow rapid visual identification of characteristics of olive oils.

The fatty acids of olive oil play a significant role in contributing to its nutritional and organoleptic quality. Various factors, such as the variety, maturity of the fruit, climatic conditions, storage and extraction process used have an effect on the fatty acid composition of olive oils. ${ }^{13,15}$

\section{CONCLUSION}

The analysis of oil from six cultivars from East and South-western Algeria has shown minor differences in their fatty acid profile.

The complete results of this analysis were obtained only with oils belonging to the six varieties produced in the season 2009 and 2010. These varieties were cultivated over several seasons to confirm the real identity of these oils, to guarantee its rank in terms of quality in the world wide market of the olive oils and to select the best varieties amongst them. This will also make it possible to select the best varieties and to spread their cultivation throughout the national territory and confirm the Algerian AOC (designation of origin controlled).

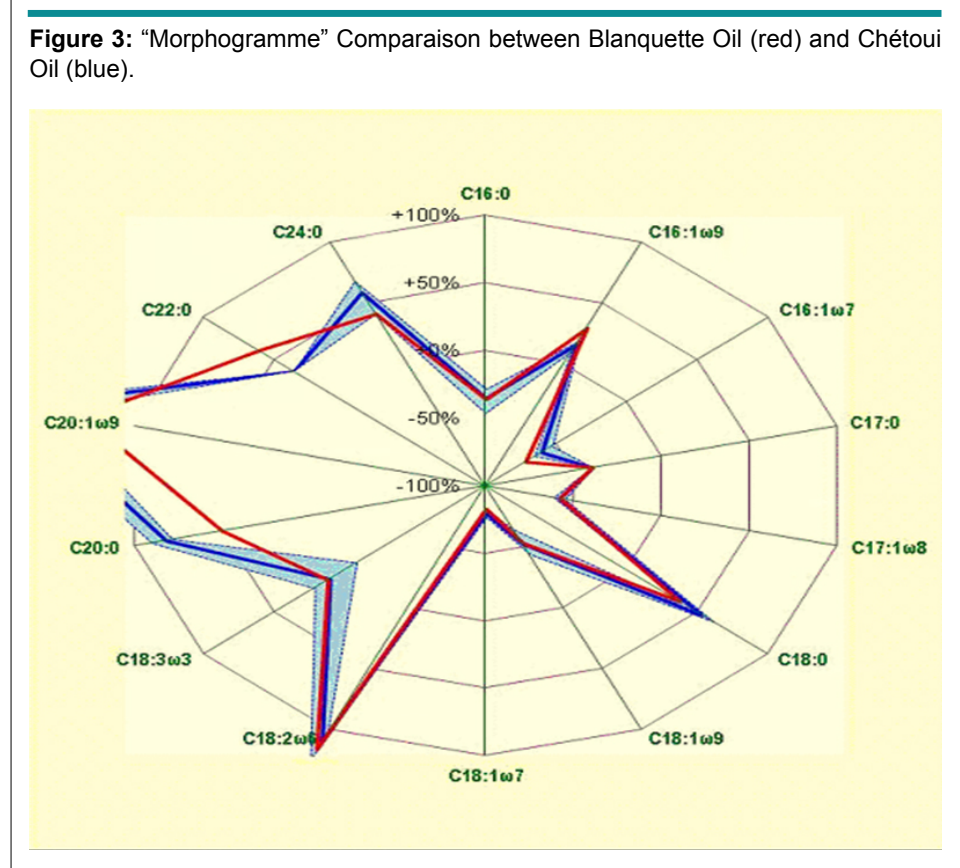


Open Journal

\section{CONFLICTS OF INTEREST}

There are no competing interests related to this article.

\section{REFERENCES}

1. D’Imperio M, Dugo G, Alfa M, Mannina L, Segre AL. Statistical analysis on Sicilian olive oils. Food Chem. 2007; 102: 956-965. doi: 10.1016/j.foodchem.2006.03.003

2. Bensemmane A. Développons le secteur de l'huile d'olive en Algérie, Filaha Innove ${ }^{\circ}{ }^{\circ}$, avril mai [In French]. 2009. Web site. http://filaha-dz.com/Filahainove/revue4.pdf. Accessed November $18,2016$.

3. Ollivier D, Artaud J, Pinatel C, Durbec JP, Guérère M. Triacylglycerol and fatty acid compositions of French virgin olive oils. Characterization by chemometrics. J Agric Food Chem. 2003; 51(19): 5723-5731. doi: 10.1021/jf034365p

4. Ollivier D, Artaud J, Pinatel C, Durbec JP, Guérère M. Differentiation of French virgin olive oil PDO by sensory characteristics, fatty acid and triacylglycerol compositions and chemometrics. Food Chem. 2006; 97(3): 382-393.

5. Olivier D. Recherche d'adultération dans les huiles végétales: Application à la qualité des huiles vierges et notamment de l'huile d'olive [In French]. Lipides. 2003; 10(4): 315. doi: 10.1051/ocl.2003.0315

6. European Standard NF EN ISO 5509 Norm. Preparation of methyl esters of fatty acids. Paris, France: AFNOR; 2000.

7. International Olive Oil Council (IOOC). Trade standard applying to olive oil and olive-pomace oil. COI/T15/NC no 3.25 June 2003.

8. Alimentarius C. Food and Agriculture Organization of the
United Nations. World Heath Organisation. Rome, Italy: Viale delle Terme di Caracalla; 2003.

9. Règlement (CEE) Européen n²568/91 de la Commission du 11 juillet 1991. Relatif aux caractéristiques des huiles d'olive et des huiles de grignons d'olive ainsi qu'aux méthodes y afférentes [In French]. J.O.C.E. 2003.

10. Zarrouk W, Haddada FM, Baccouri B, et al. Characterization of virgin oil from southern tunisia. J Lipid Science. 2008; 110(1): 81-88. doi: 10.1002/ejlt.200700085

11. Olivier D, Pinatel C, Dupuy N, Guérere M. Artaud caractérisation sensorielle et chimique d'huile d'olive vierge de six AOC française, Oléagineux [In French]. Lipides. 2007; 14(2): 141-149.

12. Bakhouche A, Lozano-Sanchez J, Bengana $M$, Guttièrrez AF, Carretera AS. Time course of algerian azeradj extra virgin olive oil quality during olive ripening. Eur J Lipid Sci Technol. 2015; 117(3): 389-397. doi: 10.1002/ejlt.201400197

13. Essiari M, Bachir S, Zouhair R, Chimi H, Misbahi H, Boudkhil M. Influence de la variété et du milieu de culture sur la composition en acides gras, en stérols et en polyphénols totaux pour les huiles vierges de quatre variétés d'olives de la région Sais (Maroc) [In French]. Euro J Sci Res. 2014; 125(1): 95-114.

14. Loussert R, Brousse G. The olive tree. In: L 'Olivier GP. Paris France: Maisonneuve \& Larose; 1978.

15. Moussaoui R, Labbaci W, Hemar N, Youyou A, Amir Y. Physico-chemical characteristics of oils extracted from three compartments of the olive fruit (pulp, endocarp and seed) of variety Chemlal cultivated in Kabylie (Algeria). J Food Agriculture Envir. 2008; 6(2): 52-55. Web site. https://pubag.nal.usda. gov/pubag/article.xhtml?id=732162. Accessed November 18, 2016. 